\title{
GAMBARAN EPIDEMIOLOGI KEJADIAN KANKER SERVIK DI RUMAH SAKIT UMUM DAERAH PROVINSI NUSA TENGGARA BARAT
}

\author{
The Epidemiological Of Cervical Cancer In General Hospital of West Nusa Tenggara \\ Province
}

\author{
Sabi'ah Khairi ${ }^{1}$, Nur Tawajjuh ${ }^{2}$, Sri Winarti $^{2}$, Ni Made Mulyani ${ }^{2}$ \\ ${ }^{I}$ Program Studi Pendidikan Ners, STIKES YARSI Mataram, Mataram, NTB, Indonesia \\ ${ }^{2}$ RSUD Provinsi Nusa Tenggara Barat, Mataram, NTB, Indonesia \\ Korespondensi: sabiahkhairi@gmail.com
}

\begin{abstract}
ABSTRAK
Kanker servik merupakan salah satu jenis penyakit tidak menular pada wanita yang menjadi fokus penanganan serta prevalensi kejadian yang semakin meningkat. Banyak faktor resiko yang dapat menyebabkan terjadinya kanker servik pada wanita terutama gaya hidup. Penelitian ini bertujuan untuk mengetahui gambaran epidemiologi penyakit kanker servik di Rumah Sakit Umum Daerah Provinsi Nusa Tenggara Barat. Desain penelitian ini menggunakan retrospective, yaitu dengan menggunakan data sekunder responden yang mengalami kanker servik di RSUD Provinsi NTB pada tahun 2017-2018. Total sampling digunakan dalam pemilihan sampel dengan total responden sebanyak 94 responden. Analisis data menggunakan presentase dari faktor resiko terjadinya kanker servik pada responden. Hasil penelitian menunjukkan bahwa 3 karakteristik yang menjadi resiko terjadinya kanker servik yaitu paritas multipara (78\%), tingkat menengah dan dasar (31\%) dan status tidak bekerja (53\%). Sedangkan dari faktor resiko lain yang mempengaruhi terjadinya kanker servik terlihat dari usia menikah dini $(62 \%)$ dan riwayat keputihan $(99 \%)$. Hasil penelitian ini diharapkan dapat menjadi informasi bagi masyarakat untuk dapat mencegah terjadinya kanker servik pada wanita dengan meningkatkan kebersihan diri terutama daerah kewanitaan agar tidak mudah terkena infeksi pada traktus gentialis dan menjaga gizi seimbang.
\end{abstract}

Kata kunci : kanker, servik, faktor resiko

\begin{abstract}
Cervical cancer is one of the non-contagious diseases that occurred among women. It has been concerned by government to tackle this disease and the disease's trend was incline in recently years. There are many factors that cause cervical cancer particularly in women's lifestyle. The purpose of this study was to determine the epidemiological of cervical cancer in general hospital of West Nusa Tenggara Province. This study used retrospective design with secondary data. The data was collected from cervical cancer patient's medical record between 2017 and 2018. 94 patients of cervical cancer have recruited as respondents in this study. Data analysis uses univariate. The result of this study shows that there were three of dominant characteristics as the risk factors that caused of cervical cancer namely multipara (78\%), low of educational level (31\%) and unemployment (53\%) while other risk factors were women who were get married under 20 years old (65\%) and abnormal vaginal discharge history (99\%). The result of this study can be used as information for people especially among women to protect themselves from the threat of cervical cancer. Women can encourage their personal hygiene and good balance nutrition for maintenance their health.
\end{abstract}

Keywords: cancer, cervical, risk factors 


\section{PENDAHULUAN}

Pembangunan kesehatan bertujuan untuk meningkatkan kesadaran, kemauan dan kemampuan hidup sehat bagi seiap orang agar terwujud derajat kesehatan masyarakat yang optimal. Untuk mewujudkan derajat kesehatan yang optimal bagi masyarakat, diselenggarakan upaya kesehatan dengan pendekatan pemeliharaan kesehatan yang dilaksanakan secara menyeluruh, terpadu dan berkesinambungan (Presiden Republik Indonesia, 2009). Namun demikian, akhir-akhir ini fokus penanganan permasalahan kesehatan di Indonesia adalah pada permasalahan penyakit tidak menular. Kanker servik merupakan salah satu jenis penyakit tidak menular pada wanita yang menjadi focus penanganan trend kejadian yang semakin meningkat.

Penyakit kanker servik atau kanker leher rahim adalah tumbuhnya sel-sel abnormal menjadi penyakit tumor ganas di leher rahim yang dapat menyebar (metastasis) ke organ-organ yang lain dan menyebabkan kematian. Tahun 2013 terjadi 528.000 kasus dengan 266.000 kematian di dunia karena penyakit kanker servik. Di Asia terjadi 175.000 kasus kanker servik dan 94.000 kematian. Kanker servik merupakan kanker dengan urutan keempat yang mempengaruhi kehidupan perempuan di seluruh dunia, setelah payudara, kolorektal, dan kanker paru-paru. Pada tahun 2013, penyakit kanker servik merupakan penyakit kanker dengan prevalensi tertinggi di Indonesia, yaitu sebesar $0,8 \% \quad(98.692$ kasus) (Kementerian Kesehatan RI, 2013). Berdasarkan data dari Badan Penelitian dan Pengembangan Kesehatan (2018), kejadian kanker servik di Indonesia tahun 2018 mencapai 23,4 per 100.000 dengan rate kematian mencapai 13,9 per 100.000 . ini merupakan fakta kejadian kanker tertiggi kedua setelah kanker payudara.

Data di RS Kanker Dharmais Jakarta menunjukkan peningkatan kasus kanker servik dari 343 kasus dan 42 kematian pada tahun 2012 meningkat menjadi 356 kasus dan 65 kematian (RS Dharmais, 2019). Provinsi Nusa Tenggara Barat (NTB) merupakan salah satu provinsi di Indonesia yang memiliki masalah kesehatan perempuan yaitu kasus kanker servik cukup tinggi, yaitu terjadi 958 kasus pada tahun 2012 (Badan Penelitian dan Pengembangan Kesehatan, 2013).

Banyak faktor risiko kanker servik yang telah dibuktikan, yaitu hubungan seksual, karakteristik pasangan, riwayat ginekologis, dietilstilbesterol, agen infeksius, human papilloma virus, virus herpes simpleks, merokok. Terdapat beberapa faktor yang yang juga diperkirakan menyebabkan kanker servik, diantaranya adalah kontrasepsi oral, diet, etnis dan faktor sosial dan pekerjaan (Rasjidi, 2009). Salah satu studi yang telah dilakukan terkait faktor-faktor yang berhubungan dengan kejadian kanker servik pada wanita usia 18 tahun dan lansia di Amerika Serikat telah menemukan bahwa status sosial ekonomi seperti wanita yang memilki tingkat pendidikan menengah atas ataupun dibawahnya serta yang berpenghasilan rendah merupakan wanita yang paling banyak terkena kanker servik (MilesRichardson, Allen, Claridy, Booker, \& Gerbi, 2016)

Penelitian yang dilakukan di Pakistan juga menemukan bahwa riwayat kontrasepsi hormonal, multigravida, dan riwayat perokok merupakan beberapa dari banyak faktor resiko terjadinya kanker servik (Zaidi, Rahman, \& Javaid, 2017). Peneliti lainnya juga memiliki pendapat yang sama bahwa faktor resiko terjadinya kanker servik dapat terjadi akibat kebiasaan merokok, seks bebas serta telah melakukan hubungan seksual pada usia remaja (Akinlotan et al., 2017). Sayangnya kejadian kanker servik ini sebagian besar baru terdeteksi ketika penderita tersebut sudah masuk pada stadium lanjut. Keterlambatan diagnosis pada stadium lanjut, keadaan umum yang lemah, status sosial ekonomi yang rendah, keterbatasan sumber daya manusia, keterbatasan sarana dan prasarana, jenis histopatologi, dan derajat pendidikan ikut serta dalam menentukan prognosis penderita (Rasjidi, 2009; Yuniar, Saryono, \& Rohani, 2009).

Rumah Sakit Umum Daerah Provinsi Nusa Tenggara Barat (RSUDP NTB) merupakan Rumah Sakit rujukan yang menerima dan menangani pasien dengan 
Sabi'ah Khairi, dkk: Gambaran Epidemiologi Kejadian Kanker Servik Di Rumah Sakit Umum Daerah Provinsi Nusa Tenggara Barat

penyakit kanker servik. Data di RSUDP NTB menunjukkan bahwa terdapat peningkatan kasus kanker servik dalam tiga tahun terakhir. Tahun 2014 terdapat 60 kasus, kemudian meningkat menjadi 72 kasus di tahun 2015. Sedangkan Tahun 2016, sampai dengan bulan Oktober terdapat 132 kasus kanker servik yang ditangani di RSUDP NTB. Sementara itu kejadian berturut-turut di RSUD Provinsi NTB pada tahun 2017 sebanyak 64 kasus dan tahun 2018 sebanyak 66 kasus (RSUD Provinsi NTB, 2019). Keterlambatan diagnosis pada stadium lanjut, keadaan umum yang lemah, status sosial ekonomi dan pendidikan yang rendah, keterbatasan sumber daya manusia, keterbatasan sarana dan prasarana, ikut serta dalam menentukan prognosis penderita. Berdasarkan sebaran data di RSDUP NTB, peneliti tertarik untuk mengetahui gambaran epidemiologi penyakit kanker servik di Rumah Sakit Umum Daerah Provinsi Nusa Tenggara Barat.

\section{TUJUAN PENELITIAN}

Tujuan penelitian ini adalah untuk mengetahui gambaran epidemiologi penyakit kanker servik di Rumah Sakit Umum Daerah Provinsi Nusa Tenggara Barat.

\section{METODE PENELITIAN}

Desain

Jenis penelitian pada penelitian ini adalah penelitian deskriptif dengan metode survey, yaitu peneliti berusaha untuk menggambarkan epidemiologi (Creswell, 2012; Sastroasmoro \& Ismael, 2014). Penelitian ini menggunakan pendekatan retrospective karena variabel yang termasuk risiko seperti, hubungan seksual, karakteristik pasangan, riwayat ginekologis, merokok, dan variabel yang termasuk efek, yaitu kanker servik di observasi secara bersamaan.

\section{Populasi dan Sampel}

Populasi penelitian ini adalah seluruh pasien kanker servik yang menjalani pengobatan di RSUD Provinsi NTB. Pengambilan sampel menggunakan teknik total sampling dengan jumlah sampel sebanyak 94 responden.

\section{Tempat dan Waktu Penelitian \\ Lokasi penelitian dilakukan di Rumah} Sakit Umum Daerah Provinsi Nusa Tenggara Barat. Waktu penelitian pada bulan September sampai dengan Desember 2019.

\section{Instrumen dan Prosedur Pengukuran}

Data yang digunakan dalam penelitian ini adalah data sekunder yang berasal dari pencatatan rekam medis (medical record) pasien yang di rawat di RSUD Provinsi NTB tahun 2017-2018. Teknik pengumpulan data dilakukan melalui studi dokumentasi. Instrumen yang digunakan dalam penelitian ini berupa lembar observasi dan pencatatan.

\section{Analisa Data}

Pengolahan data dan analisis data pada penelitian ini menggunakan statistik deskriptif.

\section{HASIL PENELITIAN}

Berikut ini dijabarkan hasil penelitian yang diperoleh dari hasil pengumpulan data. Hasil penelitian disajikan dalam bentuk tabel distribusi frekuensi yakni terdiri dari hasil penelitian terkait karakteristik sosio demografi responden dan faktor resiko yang menyebabkan terjadinya kanker servik dengan total sampel sebanyak 94 responden penderita kanker serviks di RSUD Provinsi NTB tahun 2018.

\section{Tabel 1}

Karakteristik Responden Penelitian ( $\mathrm{n}=94)$

\begin{tabular}{lcc}
\hline \multicolumn{1}{c}{ Karakteristik } & F & \% \\
\hline Usia: & 2 & 2 \\
$<30$ tahun & 29 & 31 \\
30- 45 tahun & 36 & 38 \\
$46-55$ tahun & 21 & 23 \\
$56-65$ tahun & 6 & 6 \\
$\quad>65$ tahun & & \\
Paritas & 1 & 1 \\
$\quad$ Primipara & 73 & 78 \\
Multipara & 20 & 21 \\
Grand multipara & & \\
Pendidikan & 1 & 1 \\
Tidak/belum pernah sekolah & 0 & 0 \\
Tidak tamat SD/MI & 24 & 26 \\
Tamat SD/MI &
\end{tabular}




\begin{tabular}{lcc} 
Tamat SLTP/SMP & 5 & 5 \\
Tamat SLTA/MA & 20 & 21 \\
Tamat PT & 2 & 2 \\
Tidak ada keterangan & 42 & 45 \\
Pekerjaan & & \\
Bekerja & 19 & 20 \\
Tidak bekerja & 50 & 53 \\
Tanpa keterangan & 25 & 27 \\
Status pernikahan : & & \\
Menikah & 88 & 94 \\
Janda & 6 & 6 \\
\hline
\end{tabular}

Berdasarkan data pada tabel 1 diatas, maka terlihat bahwa usia responden penelitian bervariasi yakni sebagian besar berusia diatas 30 tahun dan yang terbanyak pada rentang usia 46-55 tahun yakni sebesar $38 \%$. Untuk paritas responden, sebagian besar dari responden memiliki paritas multipara (78\%) dan sekitar $21 \%$ adalah grandmultipara, tingkat pendidikan sebagian besar tidak diketahui (45\%) tingkat dasar yakni SD sebesar $26 \%$ dan menengah yakni SLTA sebesar $21 \%$. Sedangkan untuk status pekerjaan sebagian besar tidak bekerja $(50 \%)$ dan status menikah sebesar $94 \%$.

Faktor resiko yang menyertai responden yang mengalami kanker servik dalam penelitian ini dapat dilihat pada tabel dibawah ini:

Tabel 2

Faktor Resiko Kanker Servik ( $\mathrm{n}=94)$

\begin{tabular}{lcc}
\multicolumn{1}{c}{ Karakteristik } & F & $\mathbf{\%}$ \\
\hline Usia Menikah & & \\
Remaja awal (12-15 tahun) & 4 & 4 \\
Remaja pertengahan (5-18 tahun) & 25 & 27 \\
Remaja akhir (18-20 tahun) & 29 & 31 \\
Dewasa ( $>$ 20 tahun) & 36 & 38 \\
Usia hamil pertama kali & & \\
$\quad<20$ tahun & 32 & 34 \\
>20 tahun & 62 & 66 \\
Riwayat Penyakit Menular Seksual & & \\
Riwayat Keputihan & 93 & 99 \\
Riwayat Kondiloma & 1 & 1 \\
Riwayat Kontrasepsi & & \\
Oral & 7 & 7 \\
Suntik & 69 & 73 \\
IUD & 11 & 12 \\
Implant & 9 & 10 \\
MOW & 1 & 1 \\
Tidak KB & 1 & 1 \\
Riwayat Merokok & & \\
Merokok & 2 & 2 \\
Tidak merokok & 92 & 98 \\
\hline
\end{tabular}

Berdasarkan data pada tabel 2 diatas, maka terlihat bahwa sebagian besar responden penderita kanker serviks menikah pada usia remaja atau dibawah 20 tahun. Pada tabel terlihat bahwa responden yan menikah pada usia remaja sebanyak $62 \%$ yang terbagi atas menikah pada usia remaja awal sebanyak $4 \%$, remaja pertengahan sebanyak $27 \%$ dan remaja akhir sebanyak $31 \%$. Sedangkan yang menikah pada usia dewasa ( $>20$ tahun) hanya sekitar 38\%.

Faktor resiko lain yang terlihat menonjol dari hasil penelitian ini adalah riwayat infeksi yang ditandai dengan gejala keputihan. Berdasarkan tabel tersebut terlihat bahwa sebagian besar responden (99\%) memiliki riwayat keputihan dan hanya $1 \%$ yang positif menderita infeksi kondiloma. Namun demikian data yang diperoleh terkait keputihan yang dialami responden tidak diketahui secara pasti infeksi apa yang diderita terkait adanya gejala keputihan yang dialami responden. Data lain yang dapat dilihat dari hasil penelitian adalah penggunaan kontrasepsi. Sebagian besar responden menggunakan kontrasepsi hormonal, yaitu $73 \%$ menggunakan $\mathrm{KB}$ suntik, 10\% mengunakan implant dan 7\% menggunakan KB oral.

\section{PEMBAHASAN}

Hasil analisis dari tabel distribusi frekuensi terkait faktor resiko yang mempengaruhi terjadinya kanker servik terlihat bahwa dari karakteristik demografi terdapat 3 karakteristik yang menjadi resiko terjadinya kanker servik yaitu dari paritas, tingkat pendidikan dan status pekerjaan. Sedangkan dari faktor resiko lain yang mempengaruhi terjadinya kanker servik terlihat dari usia menikah yang terlalu dini dan riwayat keputihan sebelumnya.

Salah satu penelitian yang telah dilakukan di Amerika Serikat oleh (MilesRichardson et al. (2016), yang bertujuan untuk mengetahui faktor-faktor yang berhubungan dengan kanker servik pada wanita berumur 18 tahun dan wanita usia lebih dari 75 tahun ditemukan bahwa, sebaian besar wanita yang menderita kanker servik memiliki pendidikan yang lebih rendah dan memiliki penghasilan yang 
rendah. Temuan tersebut sesuai dengan hasil penelitian ini yakni terlihat bahwa dari karakteristik demorafi yan ditemukan bahwa sebagian besar responden memiliki pendidikan setingkat SLTA atau kurang dan sebagian besar adalah ibu rumah tangga.

Status sosial ekonomi memang memiliki kaitan dengan resiko terjadinya kanker servik. Sebuah studi yang dilakukan oleh Syatriani (2011), di Makasar, menjelaskan bahwa wanita yang memiliki tingkat pendidikan yang rendah cenderung tidak mengetahui tentang kanker servik dan bagaimana pencegahannya. Seperti bagaiamana menjaga kebersihan vagina, kebutuhan nutrisi yang adekuat dan pentingnya tindakan pap smear untuk deteksi dini kanker servik. Selain itu, penghasilan yang rendah dapat memperburuk kurangnya pemahaman wanita tersebut. Hal ini dapat dikaitkan bahwa wanita yang tidak bekerja atau yang memiliki penghasilan kurang cenderung tidak memperhatikan makanan yang cukup untuk nutrisi dan status imunitasnya serta sulit menerapkan perineal hygiene yang baik untuk menjaga kebersihan area genital (Syatriani, 2011).

Karakteristik demografi lain yang dilihat menonjol dari hasil penelitian ini adalah status paritas. Hasil studi pustaka yang telah dilakukan oleh (Rasjidi, 2009) tentang epidemiologi kanker servik menjelaskan bahwa faktor resiko terjadinya kanker servik juga dapat dilihat dari jumlah kelahiran. Hal ini menujukkan bahwa semakin tinggi jumlah paritas maka resiko terjadinya kanker servik pada wanita juga semakin tinggi. Dari hasil penelitian yang telah dilakukan terlihat bahwa sebagian besar responden memiliki riwayat paritas multipara sebanyak $78 \%$ dan grandmultipara sebanyak $21 \%$.

Faktor resiko lain yang ditemukan menonjol dalam penelitian ini adalah usia menikah dini dan riwayat keputiham sebelumnya. Dari tabel distribusi frekuensi tentang faktor resiko kanker servik terlihat bahwa sebagian besar responden menikah pada usia remaja sebanyak $62 \%$. Hasil studi yang dilakukan oleh Syatriani (2011), juga menjelaskan bahwa wanita yang menikah dibawah usia 20 tahun cenderung lebih besar terkena kanker servik. Hal ini dikaitkan dengan semakin dini menikah maka semakin dini pula usia dalam melakukan hubungan seksual pertama kali. Tentu saja hal ini juga dikaitkan dengan wanita yang melakukan free sex pada usia dini memiliki resiko lebih besar terjadinya kanker servik. Organ reproduksi pada wanita usia $<20$ tahun belum memasuki fase matur, sehingga hal ini dikaitkan dengan belum siapnya organ reproduksi wanita dalam melakukan hubungan seksual pada usia dini (Syatriani, 2011).

Riwayat keputihan juga merupakan salah satu temuan tertinggi dari penelitian ini. Kondisi keputihan pada organ vital wanita biasanya mengindikasikan adanya infeksi pada organ reproduksi. Rasjidi (2009), lebih lanjut menyatakan bahwa agen infeksius pada organ reproduksi wanita memiliki resiko terkena kanker servik. Salah satu mutagen (agen infeksius) penyebab kanker servik adalah dari human papilloma virus (HPV). Virus ini yang menyebabkan terjadinya neoplasma servical sehingga pertumbuhan sel servik menjadi terganggu dan bermutasi secara massive yang menyebabkan terjadinya kanker servik. Agen infeksius lain yang juga dapat menyebabkan kanker servik adalah virus herpes simpleks, infeksi trikomonas, sifilis dan gonokokus. Namun, infeksi ini dipercaya muncul akibat hubungan seksual dengan multipel partner dan tidak dipertimbangkan sebagai faktor risiko kanker servik secara langsung (Rasjidi, 2009).

\section{KESIMPULAN}

\section{Implikasi}

Hasil penelitian terkait faktor resiko yang mempengaruhi terjadinya kanker servik di RSUD Provinsi NTB menunjukkan ada 3 faktor yang dominan dari karakteristik demorafi dan 2 faktor dari faktor resiko lainnya. Karakteritik sosio demografi yang terlihat menonjol yaitu tingkat pendidikan, pekerjaan dan paritas, sedangkan 2 faktor lainnya adalah dari faktor usia menikah dini dan riwayat keputihan. Temuan penelitian ini dapat menjadi informasi bagi masyarakat untuk dapat mencegah terjadinya kanker 
Sabi’ah Khairi, dkk: Gambaran Epidemiologi Kejadian Kanker Servik Di Rumah Sakit Umum Daerah Provinsi Nusa Tenggara Barat

servik pada wanita melalui peningkatan kebersihan diri terutama daerah kewanitaan. Selain itu wanita juga perlu memahami tentang pentingnya gizi dalam menjaga status imunitas untuk mencegah terpaparnya dengan agen infeksius penyebab kanker servik.

\section{Keterbatasan}

Penelitian ini belum mengkaji seberapa jauh korelasi beberapa faktor resiko yang mengakibatkan terjadinya kanker servik. Perlu dilakukan penelitian lebih lanjut dengan desain prospektif, sehingga dapat diketahui faktor dominan penyebab terjadinya kanker servik.

\section{DAFTAR PUSTAKA}

Akinlotan, M., Bolin, J. N., Helduser, J., Ojinnaka, C., Lichorad, A., \& McClellan, D. (2017). Cervical Cancer Screening Barriers and Risk Factor Knowledge Among Uninsured Women. Journal of Community Health, 42(4), 770-778.

Badan Penelitian dan Pengembangan Kesehatan. (2013). Riset Kesehatan Dasar (RISKESDAS) 2013. In Laporan Nasional 2013 (pp. 1-384). Jakarta: Kementerian Kesehatan Republik Indonesia.

Badan Penelitian dan Pengembangan Kesehatan. (2018). Hasil Utama RISKESDAS 2018. Jakarta.

Creswell, J. W. (2012). Research Design Pendekatan Kualitatif, Kuantitatif Dan Mixed Method. Yogyakarta: Pustaka Pelajar.

Kementerian Kesehatan RI. (2013). Info Data Kanker. Jakarta.

Miles-Richardson, S., Allen, S., Claridy, M. D., Booker, E. A., \& Gerbi, G. (2016). Factors Associated with Self-Reported Cervical Cancer Screening Among Women Aged 18 Years and Older in the United States. Journal of Community Health, 42(1), 72-77.

Presiden Republik Indonesia. UndangUndang Republik Indonesia Nomor 36 Tahun 2009 Tentang Kesehatan, Pub. L. No. 36 (2009). Indonesia.

Rasjidi, I. (2009). Epidemiologi Kanker
Serviks. Indonesian Journal of Cancer, 3(3), 103-108.

RS Dharmais. (2019). Kontribusi Data RS Kanker Dharmais dalam Registrasi Kanker Nasional. Retrieved from https://dharmais.co.id/page/137/Hasil

RSUD Provinsi NTB. (2019). Laporan Tahunan Rumah Sakit Umum Daerah Provinsi Nusa Tenggara Barat. Mataram. Retrieved from https://rsud.ntbprov.go.id/laporantahunan-laptah-rsud-provinsi-ntbtahun-2018/

Sastroasmoro, S., \& Ismael, S. (2014). Dasar-Dasar Metode Penelitian Klinis. (S. Sastroasmoro \& S. Ismael, Eds.) (5th ed.). Jakarta: Sagung Seto.

Syatriani, S. (2011). Faktor Risiko Kanker Serviks di Rumah Sakit Umum Pemerintah Dr . Wahidin Sudirohusodo Makassar , Sulawesi Selatan. Jurnal Kesehatan Masyarakat Nasional, 5(6), 283-288.

Yuniar, I., Saryono, \& Rohani, F. (2009). Faktor-Faktor Yang Mempengaruhi Kejadian Kanker Serviks di Puskesmas Karanganyar. Jurnal Ilmiah Kesehatan Keperawatan, 5(2), 109-118.

Zaidi, N., Rahman, M. U., \& Javaid, N. (2017). Awareness and Knowledge Regarding Risk Factors and Common Symptoms of Cervical Cancer Among Female Students. Pak Armed Forces Med J, 67(4), 630-634. 